\title{
A STUDY OF OXYGENATION DURING THORACOTOMY*
}

\author{
R. A. Browne, M.B., Ch.B., F.F.A.R.C.s. (ENG.), D. V. CATton, M.D., F.R.C.P.(C), \\ AND E. J. AshWORTH, M.B., B.S.(LON.) $†$
}

UP TO THE BEGINNING of the present century, operations within the thoracic cavity were greatly hampered by the "pneumothorax problem." When the chest was opened, the lung collapsed and the patient made vigorous efforts to breathe. The mediastinal structures moved violently and surgery was very difficult. Hypoxia rapidly occurred and unless the chest was soon closed, death occurred due to asphyxia.

In an effort to prevent the lungs from collapsing, certain steps were taken: (1) The patient's body and the surgeon were placed in a negative pressure chamber, with the patient's head outside the chamber. ${ }^{1}$ (2) Positive pressure was applied to the patient's airway, while breathing continued spontaneously. (3) Gases were insufflated through a catheter inserted to the carina. ${ }^{2}$ Waters $(1933)^{3}$ introduced controlled respiration using cyclopropane, but it was not until 1941 that it was widely adopted for thoracic surgery. ${ }^{4}$ It was then recognized that in this method lay the means of preventing the paradoxical respiration and mediastinal flap which occurred with spontaneous breathing.

During normal anaesthesia with the chest closed, and with intermittent positive pressure ventilation, there is rarely any problem with oxygenation in patients with normal cardiopulmonary systems, provided that at least 33 per cent oxygen is inspired and hyperventilation is employed. ${ }^{5}$

Nunn, Bergman, and Coleman ${ }^{6}$ state that there are four factors tending to lower arterial oxygen tension during anaesthesia:

1. Underventilation, associated with a high arterial carbon dioxide tension $\left(\mathrm{Pa}_{\mathrm{CO}_{2}}\right)$.

2. Increase in physiological dead space, which is known to be a regular feature of anaesthesia. ${ }^{7}$ This increase appears to be slowly progressive, and a mean increase of 33-52 per cent in physiological dead space may occur, depending on the anaesthetic agent used. The alveolar dead space shows a marked rise, while anatomical dead space is reported relatively unchanged. This increase in physiological dead space is normally compensated for under anaesthesia by hyperventilating the patient.

3. Inequalities in the ventilation/perfusion ratios.

4. Admixture of shunted venous blood with oxygenated blood leaving the pulmonary capillaries. This is probably the most important factor. Physiological shunting comprises a number of components including: (a) Pulmonary arteriovenous anastomoses. (b) Drainage of venous blood into the left heart and

'Presented at the first meeting of the Anaesthetists' Academic Association in Kingston, Jamaica, February 1968.

†Department of Anaesthesia, Hamilton Civic Hospitals.

Can. Anaes. Soc. J., vol. 15, no. 5, September 1968 
pulmonary veins. (c) Blood flow through atelectatic areas of lung. (d) Blood flow through relatively underventilated areas of lung. ${ }^{8}$ It is currently thought that under anaesthesia, increased shunting is largely due to circulation through atelectatic lung.

Nunn et al. ${ }^{8}$ have shown that venous admixture in the lungs, which is normally in the region of a 1 per cent shunt, may increase up to 10 per cent in the anaesthetized patient. In operations with the open chest, venous shunting might be expected to play an increasingly important part as the lung collapses.

The present study examines arterial oxygenation during nitrous oxide-oxygen anaesthesia in thoracic operations as time passes with the chest open, when the patient is intubated with an endotracheal or endobronchial tube. Similar studies have been carried out by Sackur $(1896)^{9}$; Bonica et al. (1961) ${ }^{10}$; and Hatch (1967) ${ }^{11}$ using different methods.

\section{METHODS}

The study was undertaken in patients who showed no signs of respiratory or cardiac insufficiency, though the majority of them were operated on for pulmonary lesions. Pulmonary function tests showed no marked abnormality. Six patients (Group I) were intubated with a cuffed endotracheal tube, while another 7 patients (Group II) were intubated with an endobronchial tube and one-lung anaesthesia was employed. The distribution of patients in the two groups according to age, sex, and operation is presented in Table I and Table II.

Anaesthesia was induced with thiopentone sodium (dose range 300-475 mg.) following premedication with meperidine (75-100 mg.) and atropine (0.6 mg.). Intubation was carried out under succinylcholine relaxation, and anaesthesia

TABLE I

Distribution of Patients in Group I

\begin{tabular}{cccll}
\hline Number & Age & Sex & \multicolumn{1}{c}{ Operation } & Pathology \\
\hline 1 & 24 & F & closure atrial septal defect & A.S.D. \\
2 & 46 & M & left upper lobectomy & carcinoma \\
3 & 55 & F & right lower lobectomy & tumour \\
4 & 56 & M & right upper lobectomy & carcinoma \\
5 & 58 & M & right upper lobectomy & carcinoma \\
6 & 63 & M & biopsy right upper lobe & inoperable carcinoma \\
\hline
\end{tabular}

TABLE II

Distribution of Patients in Group II

\begin{tabular}{|c|c|c|c|c|c|}
\hline Number & Age & Sex & Operation & Pathology & Tube \\
\hline 1 & 22 & $\mathrm{~F}$ & \multirow{7}{*}{$\begin{array}{l}\text { 1. upper lobectomy } \\
\text { 1. lower lobectomy } \\
\text { segmental resection } \\
\text { r. upper lobe } \\
\text { wedge resection } \\
\text { r. upper lobe } \\
\text { 1. lower lobectomy } \\
\text { r. upper lobectomy } \\
\text { r. upper lobectomy }\end{array}$} & cyst I. upper lobe & ML \\
\hline 2 & 28 & $\mathrm{~F}$ & & bronchiectasis l. l. lobe & Magill \\
\hline & & & & & \\
\hline 4 & 54 & M & & coin lesion & Green-Gordon \\
\hline 5 & 55 & $\mathrm{M}$ & & carcinoma & ML \\
\hline 6 & 63 & $\mathrm{M}$ & & carcinoma & $\mathrm{ML}$ \\
\hline 7 & 65 & $\mathrm{M}$ & & carcinoma & ML \\
\hline
\end{tabular}




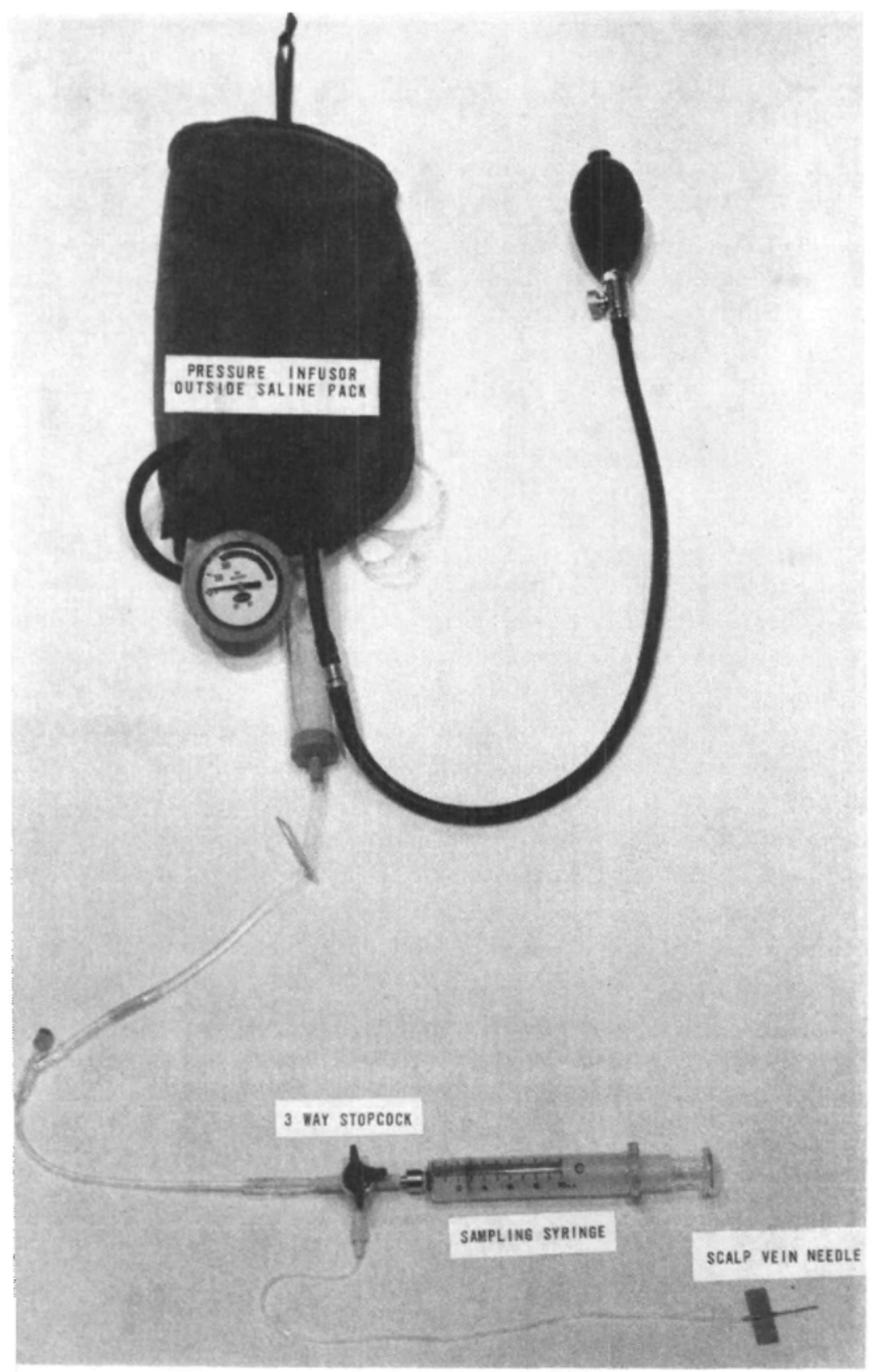

Figure 1. System for arterial sampling.

maintained by means of a semi-closed absorption system with nitrous oxide, oxygen, and a relaxant. The inspired oxygen concentration was kept between 35 and 40 per cent unless it was decided in the interest of the patient to increase it, and a constant volume mechanical ventilator (Air Shields) was used to maintain hyperventilation at 8 to $12 \mathrm{~L}$. $/ \mathrm{min}$. The pattern of ventilation was kept constant as far as possible and spot checks of the inspired oxygen concentration were taken, using the Beckman paramagnetic oxygen analyser. 


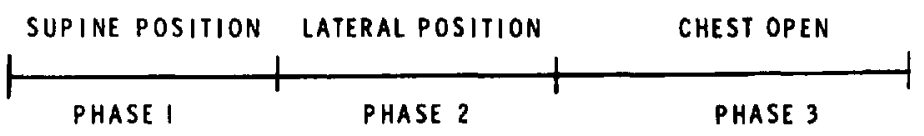

Figure 2. Sampling phases.

In both groups the period of study began after the induction of anaesthesia. Samples of arterial blood were obtained through an indwelling no. 21 scalp vein needle, inserted into the radial or brachial artery and connected to a system which was continuously flushed with heparinized saline (Fig. 1). Samples of arterial blood were easily obtained by connecting a 10 c.c. syringe, rinsed with heparin, to the free limb of a three-way stopcock and rotating the arm to connect the needle with the syringe. Blood samples were analysed for oxygen tension $\left(\mathrm{Pa}_{\mathrm{O}_{2}}\right)$ using the Clarke electrode, and for $\mathrm{pH}$ and carbon dioxide tension $\left(\mathrm{PaCO}_{2}\right)$ using the Astrup capillary electrode and micro-equilibration method. ${ }^{12}$ Sampling was carried out during the following phases in each group (Fig. 2). Phase 1-Ten minutes after induction, with the patient in the supine position. Phase 2-At tenminute intervals after the patient had been turned to the lateral position for thoracotomy, until the chest was opened. Phase 3-At 15-minute intervals after the pleural cavity had been opened, and five minutes after any re-expansion of collapsed lung or increase in oxygen concentration in the inspired gases. Sampling was discontinued in all cases after closure of the skin incision.

\section{Results}

In both Group I and Group II patients, the $\mathrm{pH}$ and $\mathrm{Pa}_{\mathrm{CO}_{2}}$ followed close limits for a given pattern of ventilation in all phases of sampling (Table III). Hyperventilation appeared to produce satisfactory levels of both these parameters.

Group I showed no significant change in arterial $\mathrm{Pa}_{0_{2}}$ in Phases 1 or 2 (Table IV), but after the opening of the chest (Phase 3) significant falls in the $\mathrm{Pa}_{\mathrm{O}_{2}}$

TABLE III

$\mathrm{PaCO}_{2}$ AND $\mathrm{pH}$ VALUES

\begin{tabular}{lcccc}
\hline & Average $\mathrm{PaCO}_{2}$ & Limits & Average $\mathrm{pH}$ & Limits \\
\hline Group I & 29 & $22-35$ & 7.48 & $7.40-7.56$ \\
Group II & 32 & $17-43$ & 7.47 & $7.37-7.58$ \\
\hline
\end{tabular}

TABLE IV

$\mathrm{PaO}_{2}$ Group I in Different Phases

\begin{tabular}{cccc}
\hline \hline Patient & Phase 1 & Phase 2 & $\begin{array}{c}\text { Phase 3 (15 min } \\
\text { post thoracotomy) }\end{array}$ \\
\hline 1 & 149 & 147 & 109 \\
2 & 184 & 188 & 146 \\
3 & 109 & 109 & 91 \\
4 & 130 & 127 & 78 \\
5 & 186 & 189 & 109 \\
6 & 147 & 145 & 111 \\
\hline
\end{tabular}


MULE AGE 58

(R) UPPER LOBECTOMY (CARCINOMU (R) UPPER LOBE BRONCHI)

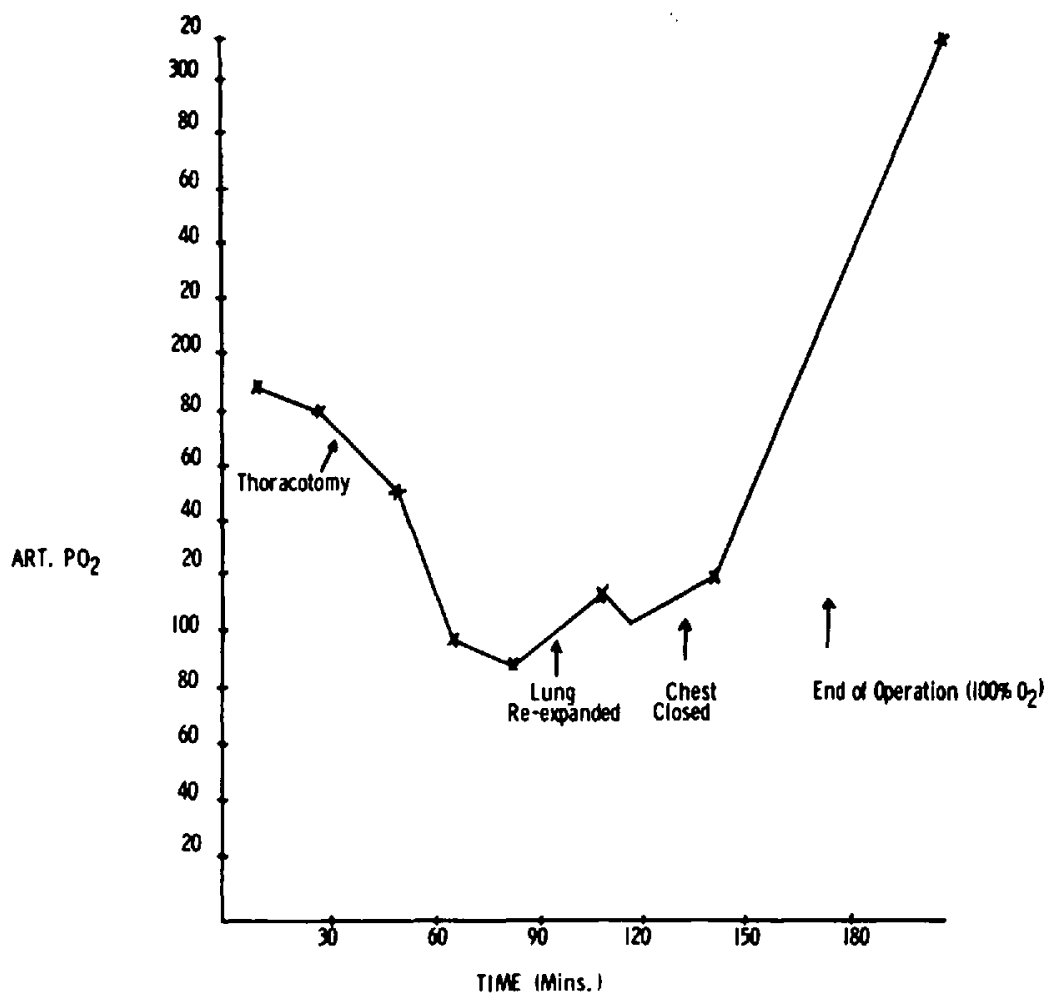

Figure 3. Typical patient in Group I.

occurred as the lung collapsed. In this group the lowest $\mathrm{Pa}_{\mathrm{O}_{2}}$ obtained after thoracotomy was $73 \mathrm{~mm}$. $\mathrm{Hg}, 13$ minutes after opening the chest, and this rose to $124 \mathrm{~mm}$. $\mathrm{Hg}$ five minutes after re-expansion of the collapsed lung. Figure 3 shows a typical example of one such case.

Group II patients showed markedly lower oxygen tensions in all phases of sampling. In Phases 1 and 2, the $\mathrm{Pa}_{\mathrm{O}_{2}}$ tended to be below $100 \mathrm{~mm}$. $\mathrm{Hg}$ (Table V), and in Phase 3, when the lung collapsed, critically low arterial oxygen tensions were obtained in some cases. In this group the lowest $\mathrm{Pa}_{\mathrm{O}_{2}}$ obtained was 42 mm. $\mathrm{Hg} 30$ minutes after thoracotomy. Figure 4 illustrates a typical example of one of the cases in this group.

TABLE V

$\mathrm{PaO}_{2}$ Group II in Different Phases

\begin{tabular}{cccc}
\hline \hline Patient & Phase 1 & Phase 2 & $\begin{array}{c}\text { Phase } 3(15 \mathrm{~min} \\
\text { post thoracotomy) }\end{array}$ \\
\hline 1 & 118 & 114 & 96 \\
2 & 78 & 75 & 58 \\
3 & 142 & 139 & 104 \\
4 & 98 & 98 & 46 \\
5 & 98 & 95 & 77 \\
6 & 96 & 93 & 69 \\
7 & 87 & 87 & \\
\hline
\end{tabular}


In both groups, inflation of the collapsed lung resulted in an immediate rise in $\mathrm{Pa}_{\mathrm{O}_{2}}$ (Fig. 4). If this was inconvenient to the surgeon, an increase in the inspired oxygen concentration also had a beneficial effect in raising the $\mathrm{Pa}_{\mathrm{O}_{2}}$, with the degree of ventilation remaining constant (Fig. 5).

\section{MALF AGE 44}

EXCISION HAMARTOMA (R) UPPER LOBE (WEOGE RESECTION)

NO. 10 MacINTOSH - LTTHERDAIE (L) ENDOBRONCHIAL TUBE

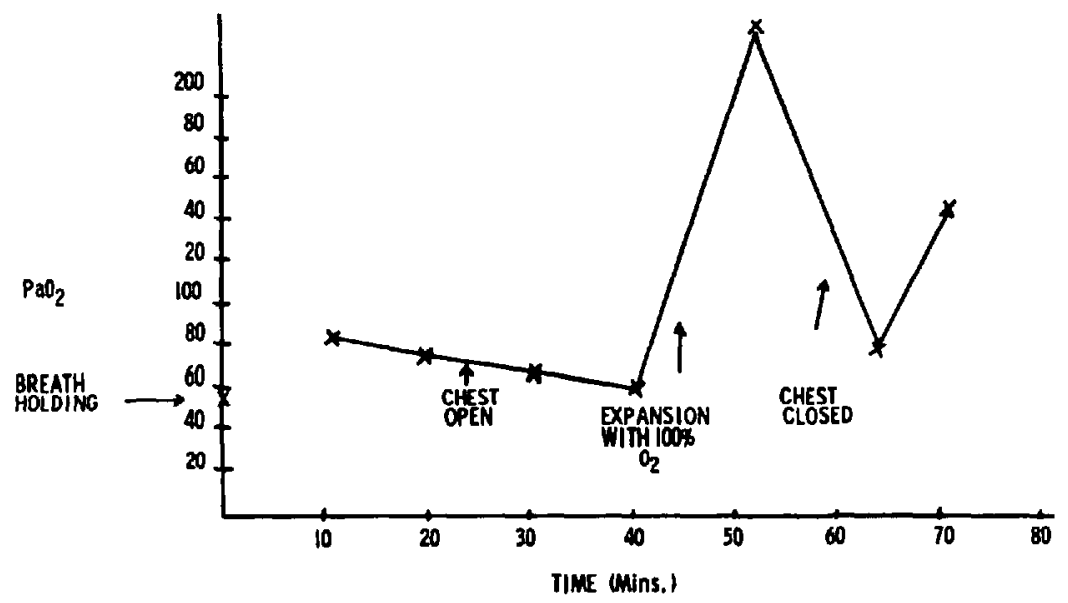

Figure 4. Typical patient in Group II.

FEMALE AGE 22

(L) UPPER LOBECTOAY (LUNG CYST)

NO. 7 MacINTOSH - LTTHERDALE TUBE

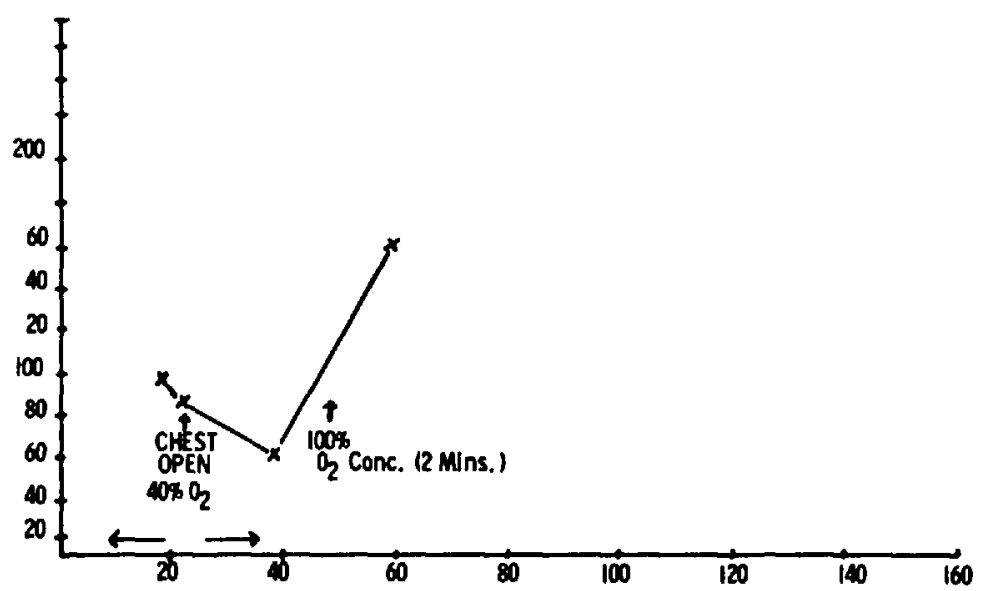

Figure 5. Effect of increasing oxygen concentration in the inspired gas mixture. 


\section{Discussion}

It is well known that the distribution of blood and gas in the lungs is altered with the patient in the lateral position. In this position the lower lung receives the greater proportion of the blood supply due to hydrostatic pressure. With the chest closed, the lower lung also receives a proportionately greater share of the ventilation because the abdominal viscera force the dependent diaphragm higher into the chest on that side; when the lungs are inflated, it consequently descends through a greater distance than the upper part of the diaphragm and a greater proportion of gas enters the lower lung. Thus the lower lung is both over-perfused and over-ventilated and its ventilation/perfusion ratio remains close to the normal value. ${ }^{13}$

In the lateral position with the chest open, the lower lung still receives the greater pulmonary blood flow, but with intermittent positive pressure ventilation the high diaphragm gives no advantage. The upper lung, which is now freed from the elastic recoil of the chest wall, can expand freely. Most of the blood therefore goes to the lower lung and most of the ventilation to the upper lung. ${ }^{14}$ The use of retractors and packs on the upper lung will, of course, reduce ventilation of this lung. These changes did not appear to make any significant difference in the $\mathrm{Pa}_{\mathrm{O}_{2}}$ when the patient in either Group I or II was turned from the supine to the lateral position before the chest was opened.

Craig et al. ${ }^{15}$ studied the changes occurring in the dependent and contralateral lung during and after thoracotomy in the lateral position. They found that atelectasis in the dependent lobes was relatively frequent during thoracotomy in the lateral position, and they concluded that its presence may easily escape detection. If this occurred, oxygenation would be further impaired.

In Group I patients, anaesthetized with an edotracheal tube, oxygen tension did not begin to fall until the lung started to collapse and, in general, hyperventilation with a nitrous oxide-oxygen mixture containing 35 to 40 per cent oxygen was satisfactory to maintain adequate oxygenation. The lowest $\mathrm{Pa}_{2}$ obtained in this group was $73 \mathrm{~mm}$. $\mathrm{Hg}$, and this suggests that an oxygen concentration of greater than 40 per cent in the inspired gases may be safer once the chest has been opened. Our results show the value of periodic re-inflation of collapsed lung which results in an immediate rise in $\mathrm{Pa}_{\mathrm{o}_{2}}$.

Group II patients, anaesthetized with an endobronchial tube, showed lower arterial oxygen tensions than those in Group I. In these patients, when the inspired oxygen concentration was 35 to 40 per cent, $\mathrm{Pa}_{\mathrm{CO}_{2}}$ values tended to be below $100 \mathrm{~mm}$. Hg even before thoracotomy was achieved. This suggests that when an endobronchial tube is used, an oxygen concentration greater than 40 per cent in the gas mixture would be safer from the beginning, and the inspired oxygen concentration should be further increased after thoracotomy. It would appear that periodic re-expansion of the collapsed lung would also be desirable in this group of patients, and that monitoring of the $\mathrm{Pa}_{2}$ would make the procedure safer. Cyanosis was not observed in any of our patients in spite of the low arterial oxygen tensions which were found.

It is therefore apparent that shunting in the lungs plays an important part in 
reducing oxygenation of the patient's arterial blood. It is markedly increased during thoracic operations, and continues into the postoperative period, where it may play the major role in postoperative hypoxaemia. ${ }^{17}$ Following thoracotomy, $\mathrm{Pa}_{\mathrm{O}_{2}}$ may not return to normal for one to two weeks. ${ }^{18}$

Nunn ${ }^{16}$ states that a $\mathrm{Pa}_{\mathrm{O}_{2}}$ that is safe for the subject while conscious will in general be safe during uncomplicated anaesthesia. He sets the adequate level of $\mathrm{PaO}_{2}$ empirically at above $100 \mathrm{~mm}$. $\mathrm{Hg}$, on the basis that this is not much less than normal for a healthy man and the level to which the body is believed to be adapted.

Slater et al..$^{5}$ take the arbitrary border between normal and abnormal oxygenation as a $\mathrm{Pa}_{\mathrm{O}_{2}}$ of $80 \mathrm{~mm}$. $\mathrm{Hg}$. They consider this to be a desirable minimum, consistent with 95 per cent utilization of oxygen carrying capacity and requiring no compensatory increase in cardiac output. The question as to what is a safe level of $\mathrm{Pa}_{2}$ for the patient has not yet been answered.

\section{SUMMariY}

A study of oxygenation in 13 patients undergoing thoracotomy is presented. Of these, six were intubated with an endotracheal tube and seven with an endobronchial tube. Marked falls in oxygen tension were found when the pleural cavity was opened, owing to increased shunting in the lungs. Increase in the inspired oxygen concentration is required when the chest is opened, and monitoring of the arterial oxygen tension is desirable when an endobronchial tube is used, as very low oxygen tensions may occur.

\section{RÉSUMÉ}

Au cours d'une anesthésie, quatre facteurs tendent à abaisser la tension d'oxygène dans le sang artériel: (1) l'hypoventilation, (2) une augmentation de l'espace mort physiologique, (3) une modification de la relation ventilation/perfusion, (4) le facteur le plus important, un mélange de sang veineux et de sang artériel quittant les capillaires pulmonaires. Au cours des opérations où le thorax est ouvert, le quatrième facteur joue un rôle d'autant plus important que le poumon est plus affaissé.

Nous avons étudié 13 malades subissant une thoracotomie. De ce total chez six malades (groupe 1) nous avons faite une intubation endotrachéale et, chez sept malades (groupe 2), une intubation bronchique. Les Tableaux I et II nous présentent les résultats.

Nous avons controlé la respiration avec un mélange de protoxyde d'azote et d'oxygène à 35 ou 40 pour cent et 1 vol./min. de 8 à $12 \mathrm{~L}$. Nous avons prélevé des échantillons de sang artériel à trois moments durant l'opération (voir Fig. 2) et nous avons recherché le $\mathrm{pH}$, la tension de $\mathrm{CO}_{2}$ et la tension d'oxygène.

Le Tableau II montre les résultats du $\mathrm{pH}$ et de la $\mathrm{Pa}_{\mathrm{Co}_{2}}$. L'hyperventilation a conservé des taux satisfaisants de ces paramètres. Groupe 1: ces malades, après l'ouverture du thorax, ont montré une chute de la $\mathrm{Pa}_{0_{2}}$ (Tableau IV). Groupe 2: ces malades ont montré une tension artérielle $\mathrm{d}^{\prime} \mathrm{O}_{2}$ inférieure à celle des malades du groupe $I$ ( Tableau V). Chez les malades des deux groupes, une réexpansion 
du poumon collabé a entrainé immédiatement une élévation de la $\mathrm{Pa}_{\mathrm{O}_{2}}$ (Fig. 4). Une augmentation du taux d'oxygène dans l'air inspiré a produit également de bons effets (Fig. 5 ).

Lorsqu'un malade est placé en position latérale et que son thorax est fermé, c'est son poumon inférieur qui est mieux ventilé et mieux perfusé. Toutefois, lorsque le thorax de ce malade est ouvert, le poumon inférieur continue à recevoir la plus grande partie du débit sanguin, mais alors, le poumon supérieur reçoit la plus grande part de la ventilation.

Craig, Bromley and Williams ont trouvé que chez les malades en position latérale, l'atélectasie des lobes en position déclive était relativement fréquente. $\mathrm{Si}$ cela s'ajoute, l'oxygénation est encore plus compromise.

Chez les malades du groupe 1, une hyperventilation avec du protoxyde d'azote et de l'oxygène à 35 ou 40 pour cent a été suffisante pour maintenir une oxygénation adéquate. Nous suggérons, une fois que le thorax est ouvert, de partir le taux d'oxygène dans l'air inspiré à au delà de 40 pour cent.

Chez les malades du groupe 2, nous avons trouvé des tensions d'oxygène inférieures dans tous les échantillons. Nous suggérons, chez de tels malades, d'élever le taux d'oxygène dans l'air inspiré et, pour la sécurité du malade, de mesurer continuellement les tensions d'oxygène.

Au cours de la chirurgie thoracique, la dérivation du sang dans les poumons est augmentée et elle continue de l'être au cours des suites opératoires durant une ou deux semaines après lesquelles la $\mathrm{Pa}_{2}$ revient à la normale.

\section{ACKNOWLEDGMENTS}

We would like to thank the Photographic Department, Hamilton Civic Hospitals, for the illustrations in this paper.

\section{REFERENCES}

1. Sauerbruch, F. Zur Pathologie des offenen Pneumothorax und die Grundlagen meines Verfahrens zu seiner ausschal tung. Mitt. Grenzgeb. Med. Chir. 13: 399 (1904).

2. Elsberg, C. A. Clinical Experiences with Intratracheal Insufflation (Meltzer) with Remarks upon the Value of the Method for Thoracic Surgery. Ann. Surg. 52: 23 (1910).

3. Waters, R. M. Carbon Dioxide Absorption from Anaesthetic Atmospheres. Proc. Roy. Soc. Med. 30: 11 (1936).

4. Noswonthy, M. D. Anaesthesia in Chest Surgery with Special Reference to Controlled Respiration and Cyclopropane. Proc. Roy. Soc. Med. 34: 479 (1941).

5. Slater, E. M.; Nilsson, S. E.; Leake, D. L.; Parhy, W. L.; Laver, M. B.; HedleyWhate, J.; \& Bendixen, H. H. Arterial Oxygen Tension Measurements during $\mathrm{N}_{2} \mathrm{O}-\mathrm{O}_{2}$ Anesthesia. Anesthesiology. 26: 642 (1965).

6. Nunn, J. F.; Bergman, N. A.; \& Coleman, A. J.: Factors Influencing Arterial $\mathrm{Po}_{2}$ during Anaesthesia with Artificial Ventilation. Brit. J. Anaesth. $37: 898$ (1965).

7. Askroc, V. F.; Pender, J. W.; SMIth, T. C.; \& ECKentofF, J. E. Changes in Respiratory Dead Space during Halothane, Cyclopropane and Nitrous Oxide Anesthesia. Anesthesiology. 25: 342 (1964).

8. Kelman, G. R.; Nunn, J. F.; Prys-Roberts, C.; \& Greenbaum, R. Influence of Cardiac Output on Arterial Oxygenation: A Theoretical Study. Brit. J. Anaesth. 39: 450 (1967).

9. SACKUR, P. Weiteres zur lehre von Pneumothorax (Virchow). Arch. Path. Anat. 150: 15 (1896). 
10. Bonica, J. J.; Wirson, J. F.; Goodson, D. N.; Ziggler, T. Q.; Murphy, T. O.; Downes, J. J.; \& TAKAmura, J. Effects of Surgical Pneumothorax on Pulmonary Ventilation. Anesthesiology. 22: 955 (1961).

11. НАтсн, D. Ventilation and Arterial Oxygenation during Thoracic Surgery. Thorax. 21: 310 (1967).

12. SiggaArd-Andersen, O.; Engel, K.; Jorgensen, K.; \& Astrup, P. A Micro Method for Determination of $\mathrm{pH}$, Carbon Dioxide Tension, Base Excess and Standard Bicarbonate in Capillary Blood. Scandinav. J. Clin. Lab. Invest. 12: 172 (1960).

13. Rothstem, E.; LANDIS, F. B.; \& NARODICH, B. G. Broncho-spirometry in Lateral Decubitus Position. J. Thoracic Surg. 19: 821 (1950).

14. Nunn, J. F. The Distribution of Inspired Gas during Thoracic Surgery. Ann. Roy. Coll. Surg. Eng. 28: 223 (1961).

15. Craig, J. O.; Bromery, L. L.; \& Williams, R. Thoracotomy and the Contralateral Lung: A Study of the Changes Occurring in the Dependent and Contralateral Lung during and after Thoracotomy in Lateral Decubitus. Thorax. 17: 9 (1962).

16. Nunn, J. F. The Significance of Oxygen Measurement. Proc. Roy. Soc. Med. 59: 905 (1966).

17. Diament, M. L. \& Palmer, K. N. V. Venous/Arterial Pulmonary Shunting as the Principal Cause of Post-operative Hypoxaemia. Lancet. 1: 15 (1967).

18. BjofK, V. O.\& H\#TY, H. J. The Arterial Oxygen and Carbon Dioxide Tension during the Postoperative Period in Cases of Pulmonary Resections and Thoracoplasties. J. Thoracic Surg. 27: 455 (1954). 